В. І. Сипченка]. - Вип. ХХ. - Слов'янськ : СДПУ, 2003. - С. 99-103. 4. Коркішко О. Г. Еколого-патріотичне виховання молодших школярів засобами народного календаря / О. Г. Коркішко // Гуманізація навчально-виховного процесу : [зб. наук. праць] / [за заг. ред. проф. В. І. Сипченка]. - Вип. XV. - Слов'янськ : СДПІ, 2001. - С. 162-170. 5. Лях Г. Проблеми трудової підготовки підростаючого покоління у зарубіжній педагогіці / Г. Лях // Гуманізація навчально-виховного процесу: [зб. наук. праць] / [за заг. ред. проф. В. І. Сипченка]. Вип. XXXI. - Слов'янськ: СДПУ, 2006. - С. 121-129. 6. Олеярник О. Професійна спрямованість старшокласників у педагогічній спадщині В. О. Сухомлинського / О. Олеярник // Гуманізація навчально-виховного процесу : [зб. наук. праць] / [за заг. ред. проф. В. І. Сипченка]. - Вип. ХXXII. - Слов'янськ : СДПУ, 2006. - С. 156-161. 7. Панасенко Е. А. Концепція створення української національної школи у педагогічній спадщині Я. Ф. Чепіги / Е. А. Панасенко // Гуманізація навчально-виховного процесу: [зб. наук. праць] / [за заг. ред. проф. В. І. Сипченка]. - Вип. XV. - Слов'янськ : СДПУ, 2001.C. $11-15$.

УДК 378.091(477)"19”

Марина Сщенко

\title{
ОРГАНІЗАЦІЯ ТА РОЗВИТОК ДОВИШІВСЬКОЇ ОСВІТИ У ВИЩИХ НАВЧАЛЬНИХ ЗАКЛАДАХ УКРАЇНИ (ДРУГА ПОЛОВИНА ХХ СТОЛІТТЯ)
}

Єщенко М. Г. Організація та розвиток довишівської освіти у вищих навчальних закладах України (друга половина ХХ століття).

У статті досліджено організацію та розвиток довишівської освіти в Україні у другій половині XX століття. Узагальнено і проаналізовано ключові твердження законодавчої бази 1948-1990-х років. Визначено мету та завдання довузівської освіти досліджуваного періоду. Доведено, що довишівська підготовка виступала необхідним елементом системи «загальноосвітня школа - вищий навчальний заклад». Обгрунтовано правила прийому, навчання та зарахування до ВНЗ випускників підготовчих курсів і відділень. Установлено, що навчання на підготовчих відділеннях здійснювали висококваліфіковані викладачі, які використовували різноманітні технології навчання. Виявлено позитивний вплив навчання на підготовчих курсах і відділеннях для подальшого вступу до ВНЗ. Охарактеризовано різні види профорієнтаційної діяльності, що сприяли популяризації вищої освіти в Україні.

Ключові слова: безперервна освіта, вища освіта, ВН3, довишівська освіта, підготовчі відділення, підготовчі курси, підготовчі факультети, профорієнтація, слухачі, студенти, школа.

Ещенко М. Г. Организация и развитие довузовского образования в высших учебных заведениях Украины (вторая половина XX века).

В статье исследовано организацию и развитие довузовского образования в Украине во второй половине XX века. Обобщены и проанализированы ключевые положения законодательной базы 1948-1990-х годов. Доказано, что довузовская подготовка выступала необходимым элементом системы «общеобразовательная школа - высшее учебное заведение». Обоснованы правила приёма, обучения и зачисления в вуз выпускников подготовительных курсов и отделений. Обнаружено положительное влияние обучения на подготовительных курсах и отделениях для дальнейшего поступления в вузы.

Ключевые слова: непрерывное образование, высшее образование, вуз, довузовское

Педагогіка вищої та середної школи. - 2015. - Вип. 45 
образование, подготовительные отделения, подготовительные курсы, подготовительные факультеты, профориентация, слушатели, студенты, школа.

Yeshchenko M.G. Organizsation and development of pre-university education in higher educational institutions of Ukraine (the second half of the $20^{\text {th }}$ century)

The article deals with the organization and development of pre-university education in Ukraine in the second half of the $20^{\text {th }}$ century. The key regulations of the law base of $1948-1990$ are generalized and analyzed. It is proved that pre-university preparation was necessary element for the system «secondary school - higher educational institution». The rules of admission, education and enrollment of the graduates of the preparatory courses and departments in an educational institutions are substantiated. The positive influence of education at the preparatory courses and departments for the further enrollment in an educational institutions was revealed.

Key words: lifelong learning, higher education, higher educational institution, pre-university education, preparatory departments, preparatory courses, preparatory faculties, career guidance, trainees, students, school.

Розбудова національної системи освіти, вихід вітчизняної науки й техніки на світовий рівень, інтеграція до європейського та світового освітнього простору вимагає високого рівня професійної підготовки підростаючого покоління. Закони України «Про освіту», «Про загальну середню освіту», Національна доктрина розвитку освіти України у ХХІ столітті вказують на необхідність підвищення загальнокультурного рівня випускників та їхньої професійної орієнтації.

Накопичений вітчизняною історією досвід розвитку довишівської освіти в Україні у другій половині XX століття становить вагомий інформаційний пласт, який недостатньо вивчений i, відповідно, не відображений у науковій літературі. Аналіз історико-педагогічних досліджень, присвячених питанню довишівської освіти в Україні другої половини ХX століття та виявлення головних тенденцій становлення довузівської підготовки наразі сприятиме, на нашу думку, уникненню помилок і віднайденню засобів оптимізації довишівської освіти в умовах сьогодення.

Вивчення науково-педагогічних джерел свідчить про те, що проблема розвитку безперервної освіти, у тому числі й довишівської, була в центрі уваги вітчизняних науковців. Суттєвий внесок у розроблення концептуальних тверджень довишівської підготовки зробили: Л. Апостолов, . Бабаєв, П. Говоров, І. Гусь, Г. Жовта, М. Капелевич, . Кривонос, Л. Лазаренко, С. Мауріна, А. Нестеренко, Л. Новікова, І. Сладких, С. Сошенко, В. Тарасевич та ін.

Філософсько-соціологічні, управлінські аспекти проблеми довишівської освіти знайшли своє відображення у працях сучасних науковців: Ю. Ніколаєва, І. Совгір, Г. Філіпчука, Н. Чернова та ін. Дидактичні аспекти управління якістю шкільної та довівської освіти висвітлено в наукових розвідках Н. Бібік, В. Бондаря, М. Бурди, Н. Буринської,
С. Гончаренка,
С. Ковалевського,
В. Мадзігона,
В. Маслова,
В. Паламарчук,

Є. Павлютенкова та ін.

Проблема розвитку довишівської освіти стала предметом наукового пошуку багатьох науковців у таких напрямах: організаційно-педагогічні засади навчання слухачів факультету довишівської підготовки (І. Бичкова); професійне самовизначення старшокласників в освітньому процесі системи довишівської підготовки (Л. Кравчук); активізація пізнавальної діяльності слухачів підготовчого відділення, зорієнтованих на здобуття педагогічної професії 
(Л. Ройко); педагогічні умови довишівської підготовки учнів (Н. Самаркіна); організаційнопедагогічні засади управління центром довишівської підготовки вищого навчального закладу (Е. Фатєєва); довишівської підготовка майбутніх студентів у системі безперервної педагогічної освіти (В. Федяєва); соціально-педагогічні умови функціонування системи довишівської освіти (Д. Філіппов) тощо.

Mema cmammi полягає у грунтовному аналізі проблеми організації та розвитку довишівської підготовки у вищих педагогічних навчальних закладах України у другій половині ХХ століття.

Питання якості вищої освіти завжди перебували в поді посиленої уваги фахівців вищої школи. У другій половині ХХ століття у зв'язку з підвищенням вимог до якості вищої освіти ці питання набули особливого значення. Зокрема, мала місце проблема вдосконалення методів і форм підготовки кадрів вищої кваліфікації. Як один із заходів розв'язання цієї проблеми було запропоновано розширення мережі довишівської підготовки.

У другій половині XX століття довишівська підготовка в різних навчальних закладах була необхідним елементом системи «загальноосвітня школа - вищий навчальний заклад».

Грунтовне ознайомлення з документами періоду післявоєнної відбудови народного господарства дозволило визначити певні особливості, а саме:

- відсутність бажання виробничої молоді вступати у ВНЗ, що спричинило розбіжності в соціальному складі вищої школи з соціальною структурою суспільства. Виникла проблема недостатньої кількості висококваліфікованих фахівців у сільській місцевості тому, що випускники ВНЗ із міст не бажали працювати лікарями, учителями, інженерами, агрономами в селах;

- відсутність механізму залучення до вищої школи робітничої й сільської молоді, i, як наслідок, кількість абітурієнтів зазначеної категорії була недостатньою [3, с. 14-19].

Отже, така ситуація вимагала негайних змін. У травні 1948 року Рада Міністрів СРСР прийняла постанову № 1729 «О курсах по подготовке к поступлению в высшие и средние специальные (техникумы) учебные заведения», яка передбачала:

1. Уведення 31 вересня 1948 року платного навчання на підготовчих курсах i відділеннях при вищих і середніх спеціальних (технікумах) навчальних закладах.

2. Підготовчі відділення при вищих і середніх спеціальних (технікумах) навчальних закладах можуть бути організовані лише з дозволу Міністерства вищої освіти СРСР на засадах повної самоокупності.

3. На підготовчі курси й відділення можуть прийматися особи, які мають середню освіту (при ВНЗ) та які закінчили 7 класів середньої школи (при технікумах) [5, с. 1-2].

У 1969 році згідно з постановою ЦК КПРС і Ради Міністрів СРСР «...3 метою підвищення рівня загальноосвітньої підготовки робочої та сільської молоді й створення їй необхідних умов для вступу до вищої школи» у ВНЗ було відкрито підготовчі відділення [4, c. 107-110].

Плани прийому на підготовчі відділення та форма навчання встановлювалися Держпланом СРСР за участі Міністерства вищої та середньої спеціальної освіти СРСР. Підготовчі відділення було організовано при вищих навчальних закладах, які здійснювали підготовку фахівців за денною формою навчання, за наявності у відділенні не менше 100 слухачів [4, с. 107-110].

Прийом на підготовче відділення здійснювався комісією у складі завідувача відділення, представників партійних, профспілкових і комсомольських організацій вищого 
навчального закладу, викладачів профільних дисциплін. Комісія, відповідно до затвердженого плану прийому, здійснювала набір шляхом співбесіди 3 кожним вступником, 3'ясовуючи його спроможність до навчання на підготовчому відділенні. Зарахування на підготовче відділення проводилося за підсумками співбесіди наказом ректора ВНЗ. Особам, зарахованим на підготовче відділення, видавався квиток слухача [4, с. 107-110].

У 1970-х роках у «Бюлетні Міністерства вищої та середньої спеціальної освіти СРСР», 1971 (№ 8), Міністерством вищої і середньої спеціальної освіти СРСР було вказано, що при вищих навчальних закладах, середніх загальноосвітніх школах, установах, промислових підприємствах, будовах, у радгоспах і колгоспах організовано широку мережу курсів із підготовки молоді до вступу у ВН3 [4, с. 107-110].

Більшість вищих навчальних закладів систематично проводили роботу щодо вдосконалення якості та рівня підготовки слухачів курсів, сприяли забезпеченню викладання на високому навчально-методичному рівні, широко використовували в навчальному процесі технічні засоби навчання (кіно, діафільми, діапозитиви, навчальні та контролювальні машини, різноманітні методичні матеріали тощо), що допомагало у здійсненні єдиної спрямованості навчального процесу відповідно до вимог ВНЗ. Також до роботи на курсах залучалися висококваліфіковані викладачі [4, с. 107-110].

Характерним є те, що підготовчі відділення та курси були досить популярними серед молоді. Систематичні заняття на них за умов якісної організації роботи давали грунтовні знання, необхідні для складання вступних іспитів і подальшого успішного навчання у ВНЗ. Особи, які закінчили підготовчі відділення й успішно склали випускні іспити, зараховувалися на І курс ВНЗ без складання вступних іспитів [4, с. 107-110].

Перші роки діяльності підготовчих відділень дозволили досить високо оцінити їхню роль у регулюванні соціального складу студентів, незважаючи на деякі витрати етапів становлення [3, с. 14-19].

Так, згідно з Наказом № 538 від 02.10 .1980 р. «О плане приёма слушателей на подготовительные отделения вузов» відповідно до листа Дежплану УРСР від 11.01.1980 року № 22-38/10 було визначено план на 1980 рік [7, с. 17-18]. А у грудні 1980 року за № 1430 Наказом Міністерства вищої і середньої спеціальної освіти СРСР було видано «Інструкцію про порядок організації і роботи курсів із підготовки до вступу у вузи й середні спеціальні навчальні заклади», у яких було представлено умови створення курсів, - хто може бути слухачем курсів, які документи необхідно надати для навчання на курсах (довідка про сплату за навчання, довідка 3 місця роботи або навчання, військовий квиток), зазначалися також права слухачів курсів (користування бібліотекою, лабораторіями, технічними засобами кафедр тощо). Слід зауважити, що до навчального процесу залучалися не тільки викладачі ВН3, на курсах також викладали вчителі загальноосвітніх шкіл [6, с. 1-2; 10, с. 1-2].

Важливо зазначити, що крім плану прийому, відповідним рішенням колегії № 14107/210 від 26.03.1981 року «Об итогах приёма на подготовительные отделения в 1980 году» Міністерство приймало звіти вищих навчальних закладів щодо виконання плану. Отже, міністерство координувало діяльність підготовчих відділень й управляло їх діяльністю.

Наказ Міністерства вищої та середньої спеціальної освіти СРСР № 504 від 14 липня 1987 року «Об утверждении положения о подготовительном отделении при высшем учебном заведении» дозволяв зараховувати на підготовчі відділення громадян СРСР, які закінчили середню освіту й мали стаж роботи в усіх галузях народного господарства не менш ніж 2 роки, що на рік більше, ніж це було запропоновано в 1969 році. Зарахування на підготовчі відділення здійснювалося на підставі рішення приймальної комісії; порівняно з попередніми 
роками зарахування відбувалось автоматично, тільки на підставі клопотання керівника підприємства.

Відтепер у ВНЗ на підготовчих відділеннях готували студентів не лише для свого навчального закладу, а й для інших закладів вищої школи на відповідні спеціальності. Стипендія слухачів підготовчих відділень залежала від стажу роботи й була на $30 \%$, а за наявності стажу більше 3 років - на 50\% вище, ніж установлена стипендія першокурсника. До цього часу стипендія слухачам підготовчих відділень виплачувалась у розмірі, який був установлений для студентів першого курсу ВНЗ, при якому організовано підготовче відділення. По закінченню підготовчого відділення слухачі отримували відповідне посвідчення, завізоване ректором або проректором ВНЗ, яке було необхідне для вступу в інший вищий навчальний заклад. Зарахування відбувалось на перший курс без вступних іспитів за умови успішного складання випускних іспитів на підготовчих відділеннях, про що свідчила екзаменаційна картка [8, с. 1-2].

Ефективність підготовки у ВНЗ висококваліфікованих кадрів багато в чому визначалася складом студентства. Саме тому діяльність колективів закладів вищої школи в другій половині XX століття в Україні передбачала активне залучення випускників загальноосвітніх шкіл до освітніх установ та формування в них відповідального ставлення до навчання.

Із метою популяризації вищої освіти у ВНЗ використовувалися різні форми, серед яких найбільш масовою була професійна інформація. Деканати навчальних закладів широко практикували «Дні відкритих дверей». На факультетах перед молодю виступали декани, науковці, викладачі та студенти. У ці дні працювали кабінети, лабораторії та музеї. Професорсько-викладацьким складом проводилися лекції, організовувалися консультації для учнів старших класів. Також до шкіл розсилали оголошення про новий прийом, організовували олімпіади серед абітурієнтів, бесіди по радіо й телебаченню, виступи науково-педагогічних робітників і випускників ВНЗ у періодичній пресі.

Окрім цього, педагогічні колективи ВНЗ установлювали постійні зв'язки зі школами, промисловими підприємствами, колгоспами, радгоспами, військовими частинами тощо.

Грунтовний аналіз проблеми організації та розвитку довишівської підготовки в Україні в другій половині XX століття дозволяє констатувати, що цьому питанню приділялась значна увага. Представники уряду УРСР, керівництво вищих та середніх навчальних закладів, промислових підприємств, колгоспів, радгоспів, військових частин брали активну участь в організації довишівської освіти та залученні учнівської молоді на підготовчі відділення.

У ході дослідження встановлено, що організаційні форми довишівської підготовки функціонували як структурні складові вищих навчальних закладів (очно-заочні школи, підготовчі курси та відділення, факультети довишівської підготовки); установ середньої освіти (профільні класи, факультативи за вибором); інститутів неперервної освіти; освітніх інституцій, у яких частину функцій реалізували заклади середньої освіти, а іншу - вищі навчальні заклади. У школах значно активізувалась профорієнтаційна робота, поглиблено вивчалися предмети професійного спрямування.

Отже, вищі навчальні заклади зазнали суттєвих змін у змісті, формах, методах і технологіях навчання слухачів відповідно до реформаційних процесів у системі освіти, що позитивно вплинуло на розбудову різних галузей народного господарства та досягнення наукової думки в другій половині ХХ ст. 


\section{Література}

1. Апостолов Л. Г. Проблемы оптимизации взаимосвязей в системе «Университет средняя школа»/ Л. Г. Апостолов // Проблемы высшей школы. - Республиканский научнометодический сборник. - Киев : Высшая школа, 1981. - Вып. 43. - С. 41-45. 2. Вища школа Української РСР за 50 років: у 2 ч. - Київ: Вид-во Київ. ун-ту, 1967. - Ч. 1. - С. 395. 3. Жовтая Г. Н. Подготовительные отделения в вузах: вчера, сегодня, завтра./ Г. Н. Жовтая // Проблемы высшей школы. - Республиканский научно-методический сборник. - Киев : Высшая школа, 1991. - Вып. 74. - С. 14-19. 4. Подготовительные отделения и подготовительные курсы при высших учебных заведениях // Высшая школа: [сборник основных постановлений, приказов и инструкций].- Москва: Высшая школа, 1978. - Часть I. - С. 107-110. 5. Постановление № 1729 от 22.05 .1948 г. «О курсах по подготовке к поступлению в высшие и средние специальные (техникумы) учебные заведения», Совет Министров СССР с изменениями и дополнениями, внесенными Постановлением Совмина СССР от 05.11.1970 № 907. [Электронный ресурс]/ Режим доступа: http://www.alppp.ru/law/ obrazovanie-nauka-kultura/obrazovanie/41/postanovleniesovmina-sssr-ot-22-05-1948-1729.html 6. Приказ №1430 от 29.12.1980 г. «Об утверждении инстукции о порядке организации и работе курсов по подготовке к поступлению в высшие и средние специальные учебные заведения» Министерство высшего и среднего специального образования СССР [Электронный ресурс]/ Режим доступа: http://poisk.7law.info/ussr/ act2d/ g881.htm 7. Приказ № 538 от 02.10.1980 г. «О плане приёма слушателей на подготовительные отделения вузов» в соответствии с письмом Госплана УССР от 11.01 .80 года № 22-38/10. // Сборник приказов, инструкций и других нормативных актов МИНВУЗА УССР № 4 (за IV квартал 1980 г.). - Киев, 1980. - С. 17-18. 8. Приказ № 504 от 14.07.1987 г. «Об утверждении положения о подготовительном отделении при высшем учебном заведении» Министерство высшего и среднего специального образования СССР [Электронный ресурс] / Режим доступа : http://www. libussr.ru/ doc_ussr/usr_14135.htm 9. Приказ № 504 от 19.07.1990 г. «Об утверждении типового положения о курсах при высших и средних специальных учебных заведениях» Государственный комитет СССР по народному образованию [Электронный pecypc]/ Режим доступа: http://uristu.com/library/sssr/?dir\%5B0\%5D= sssr\&PAGEN_1=31 10. Решение коллегии № 14-107/210 от 26.03.1981 г. «Об итогах приёма на подготовительные отделения в 1980 году» в соответствии с Решение коллегии № 14-107/210 от 26.03.1981 г. // Сборник приказов, инструкций и других нормативных актов МИНВУЗА УССР № 4 (за IV квартал 1980 г.). - Киев, 1981. - С. 257-260. 11. Сошенко С. М. Організація освітньої діяльності довузівської підготовки / С. М. Сошенко // Засоби навчальної та науководослідної роботи : [зб. наук. праць Харьк. нац. пед. ун-т ім. Г. С. Сковороди]. - 2010. Вип. 33. - С. 148-157. 12. Тарасевич В. В. По системе «школа - педвуз - школа»/ В. В. Тарасевич, И. Ф. Кривонос // Вестник высшей школы. - 1985. - № 6. - С. 13-15. 13. Фатєєва Е. М. Організаційно-педагогічні засади управління центром довузівської підготовки вищого навчального закладу : дис. ... канд. пед. наук: 13.00 .01 / Е. М. Фатєєва. Херсон, 2005. - С. 17-19. 